\title{
Occurrence and paleoecological significance of lyssacinosid sponges in the Upper Cretaceous deposits of southern Poland
}

\author{
Ewa Świerczewska-Gładysz • Agata Jurkowska
}

Received: 26 April 2012 / Accepted: 12 October 2012/Published online: 2 November 2012

(C) The Author(s) 2012. This article is published with open access at Springerlink.com

\begin{abstract}
Cretaceous lyssacinosid sponges (Hexactinellida) are rare and poorly recognized. This is the first description of lyssacinosid sponges from the Cretaceous of Poland. The sponges (including six species and three types of root tufts) come from the Upper Turonian-Lower Coniacian of the Opole Trough, Upper Campanian of the Miechów synclinorium, and Upper Campanian of the SE part of the border synclinorium. All localities lie southwards of the previous reports, widening thus the paleogeographic distribution of the group within the North European Province. Cretaceous lyssacinosids seem to be a useful tool in paleoecological interpretations. The presence of thin-walled lyssacinosids with root tufts indicates a soft substrate, slow rate of sedimentation, and calm and deeper water conditions.
\end{abstract}

Keywords Sponges - Hexactinellida - Lyssacinosida . Paleoecology · Upper Cretaceous · Southern Poland

\section{Introduction}

Sponges of the order Lyssacinosida Zittel, 1877 (subclass Hexasterophora Schulze, 1886) are a group of siliceous sponges of the class Hexactinellida Schmidt 1870, commonly referred to as "glass sponges". Their oldest

\footnotetext{
E. Świerczewska-Gładysz

Institute of Earth Science, University of Lodz,

Narutowicza 88 St, 90-139 Lodz, Poland

e-mail: eswiercz@geo.uni.lodz.pl

A. Jurkowska ( $\square)$

Institute of Geological Sciences, Jagiellonian University,

Oleandry 2a St, 30-063 Krakow, Poland

e-mail: jurkowska.a@gmail.com
}

representatives are known from the Upper Proterozoic (Gehling and Rigby 1996). Mesozoic lyssacinosids are rare and poorly recognized. Few assemblages of these sponges are known from the Triassic of Utah and Nevada (Rigby and Gosney 1983), China (Wendt et al. 1989; Wu 1989) and Poland (Pisera and Bodzioch 1991; Bodzioch 1993, 1994). Jurassic lyssacinosids were described from Germany (Zittel 1877; Schrammen 1937), Morocco (Dresnay et al. 1978) and Argentina (Beresi 2003). Their presence in Triassic and Jurassic reef biota in the Alpine Region is documented by loose spicules (Mostler 1989; Delecat and Reitner 2005; Delecat et al. 2011).

Occasionally, lyssacinosids appear in Upper Cretaceous sponge assemblages of the North European Province, which consists mainly of other hexactinellids (Hexactinosida and Lychniscosida) and lithistids. Best known are Coniacian lyssacinosids from Bornholm (Mehl 1992; Brückner and Janussen 2005; Brückner 2006). However, single species of Lyssacinosida were also identified in the Cenomanian of Normandy (Moret 1926), Lower Cenomanian and Campanian of northwest Germany (Schrammen 1912; Salomon 1990), and from the Chalk of England (Bowerbank 1869; Reid 1968). Lyssacinosida have never been documented from the Upper Cretaceous of Poland.

Because the skeleton of lyssacinosid sponges is composed of unfused, or only locally connected spicules, their fossilization potential is definitely lower than that of other siliceous sponges with a rigid skeleton (e.g., Krautter 2002). The poor preservational state of these sponges in the Upper Cretaceous is the reason for their poor taxonomic recognition. Root tufts of lyssacinosid sponges composed of long basal spicules, occurring in the Upper Cretaceous deposits of southern Poland, were mentioned in the literature as sea grasses (Rutkowski 1965) or plants (Roemer 1870, pl. 30, fig. 2; Kędzierski 1995). 
This paper aims to describe the lyssacinosid sponges from the Upper Turonian-Lower Coniacian of the Opole Trough, Upper Campanian of the Miechów synclinorium, and the SE part of the border synclinorium (Middle Vistula River section). In addition, their importance in paleoecological reconstructions is discussed.

\section{Materials and methods}

The studied collection of lyssacinosid sponges comprises 98 specimens. The material was collected from three sections in the Miechów synclinorium (Rzeżuśnia, Strzeżów Jędrzejów), a single section in the SE part of the border synclinorium (Piotrawin), and a single section in the Opole Trough (Folwark quarry) (Fig. 1a-c). Details of the skeleton were analyzed under a stereoscope microscope at the Institute of Geological Sciences of the Jagiellonian University, Krakow. Thin-sections and rock samples were also analyzed under an optical microscope.

The studied specimens are hosted at the Institute of Geological Sciences of the Jagiellonian University, Krakow, collection no UJ220P, and in the Laboratory of Geology of the University of Lodz (collection no. ULXXIII).

\section{Localities}

In the extra-Carpathian Poland, Upper Cretaceous rocks crop out in the Southern Polish Uplands, in the Opole Trough, and in the Sudety Mountains (Fig. 1a). The so-called mid-Cretaceous eustatic transgression started in the middle Albian, covering rapidly most of its territory (Pożaryski 1960; Marcinowski 1974; Marcinowski and Radwański 1983, 1989). The initial facies variability of the Albian and Cenomanian was quickly followed by a uniform facies during the Early Turonian. With the exception of the Sudetes, where siliciclastic sedimentation prevailed, the rest of the area is characterized by limestone-marly facies (Central Polish Uplands); limestones are restricted to the Krakow Swell area, while in other regions opoka (siliceous limestone)/marly facies dominate (Marcinowski 1970, 1974; Walaszczyk 1992; Voigt et al. 2008).

\section{Opole Trough}

The Cretaceous succession of the Opole Trough spans the Cenomanian to Middle Coniacian time interval (Walaszczyk 1992).

The Folwark section is an active quarry of the cement industry, located about $10 \mathrm{~km} \mathrm{SW}$ from the city of Opole (Fig. 1a). The 54-m-thick succession (Fig. 1b) is composed
Fig. 1 a Tectonic sketch map of Poland without the Cenozoic cover (after Marcinowski and Radwański 1983, simplified), and location of the study area. b, c Geological columns of the studied sections; b inoceramid zonation based on Walaszczyk 1992; Walszczyk and Wood 1998 and Walaszczyk and Cobban 2000; c inoceramid zonation based on Walaszczyk 2004; Walaszczyk et al. 2008 and Jagt et al. 2004

of Upper Turonian to Lower Coniacian deposits (Walaszczyk 1988, 1992; Tarkowski 1991; Kedzierski 2008). p. 4 line 92-97: The lower part of the succession (Marly Limestone Unit, after Alexandrowicz and Radwan 1973) is represented by marly limestone with very thin intercalations of dark-grey argillaceous marl belonging to the Inoceramus perplexus Zone (=I. costellatus, see Walaszczyk and Cobban 2000) and lower part of the Mytiloides scupini Zone (Walaszczyk 1992; Walaszczyk and Wood 1998). Overlying gray marl with intercalations of dark-grey argillaceous marl and light-grey siliceous marl (Upper Marl Unit after Alexandrowicz and Radwan 1973) belongs to zones of Mytiloides scupini, Cremnoceramus waltersdorfensis waltersdorfensis, C. deformis erectus, and of C. crassus crassus $+C$. deformis deformis (Walaszczyk 1992; Walaszczyk and Wood 1998). Microfacially, marls from the studied section represent wackestone with foraminifera and rare sponge spicules (Fig. 2a). Organic components also comprise fragments of bivalves and rare echinoids. Detritic material is insignificant. The highest part of the succession is represented by thin $(0.5 \mathrm{~m}) \mathrm{soft}$, argillaceous marl (Upper Argillaceous Marl Unit after Alexandrowicz and Radwan 1973). The whole succession is relatively fossiliferous, with abundant inoceramids and ammonites (Walaszczyk 1988; Tarkowski 1991), echinoids (Olszewska-Nejbert 2007), and sponges (numerous hexactinosids and lychniscosids, rare lithistids) (Roemer 1870; Leonhard 1897; Tarkowski 1991). The whole succession has been intensively bioturbated (Kędzierski and Uchman 2001).

Rare lyssacinosid sponges occur in the Upper Marl Unit. All specimens are strongly pyritized with only single siliceous spicules preserved.

\section{Miechów synclinorium}

In the Miechów synclinorium, Cretaceous strata are represented by Upper Albian through to Lower Maastrichtian (Rutkowski 1965; Marcinowski 1974; Heller and Moryc 1984; Hakenberg 1986; Walaszczyk 1992; Świdrowska and Hakenberg 1999). The lyssacinosids were collected from three sections; two located in the southern part of the synclinorium (Rzeżuśnia and Strzeżów), and one in its northern region (Jędrzejów) (Fig. 1a, c).

The Rzeżuśnia section is an inactive quarry with exposed lower Upper Campanian [Inoceramus azerbaydajensis/ 


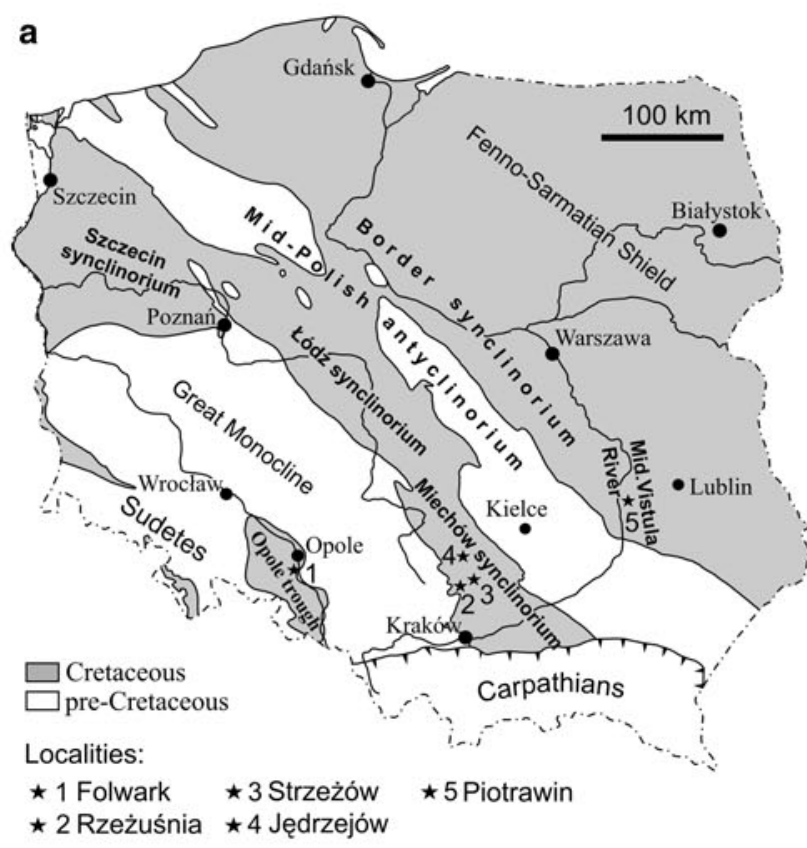

b
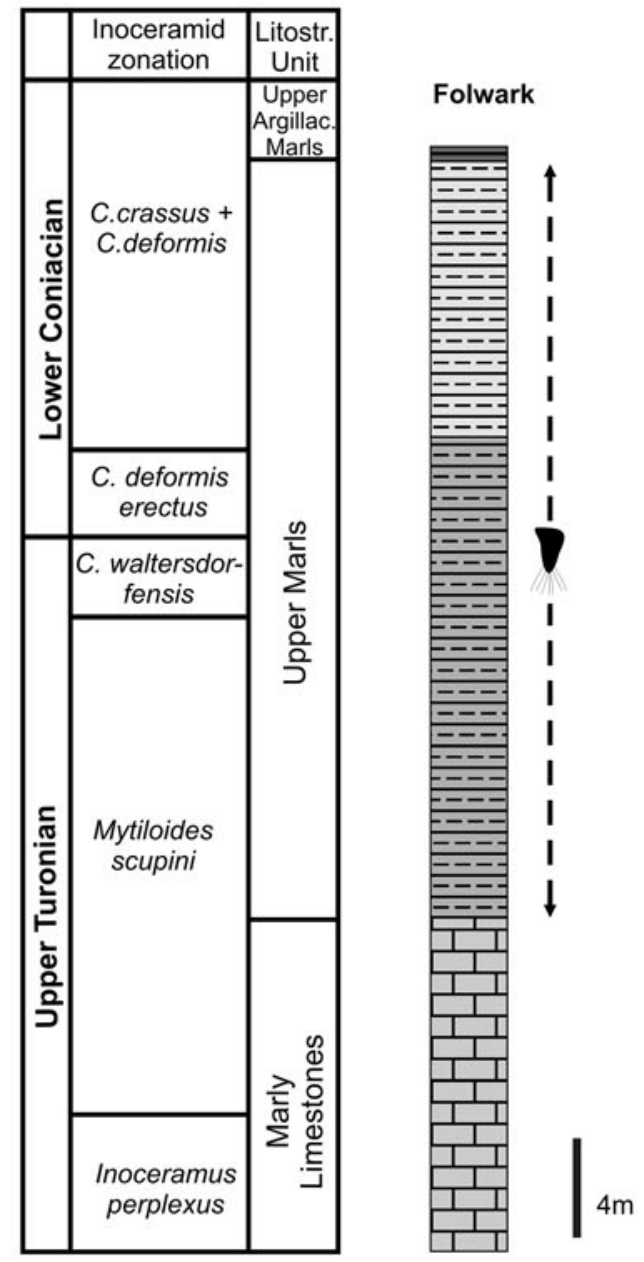

c
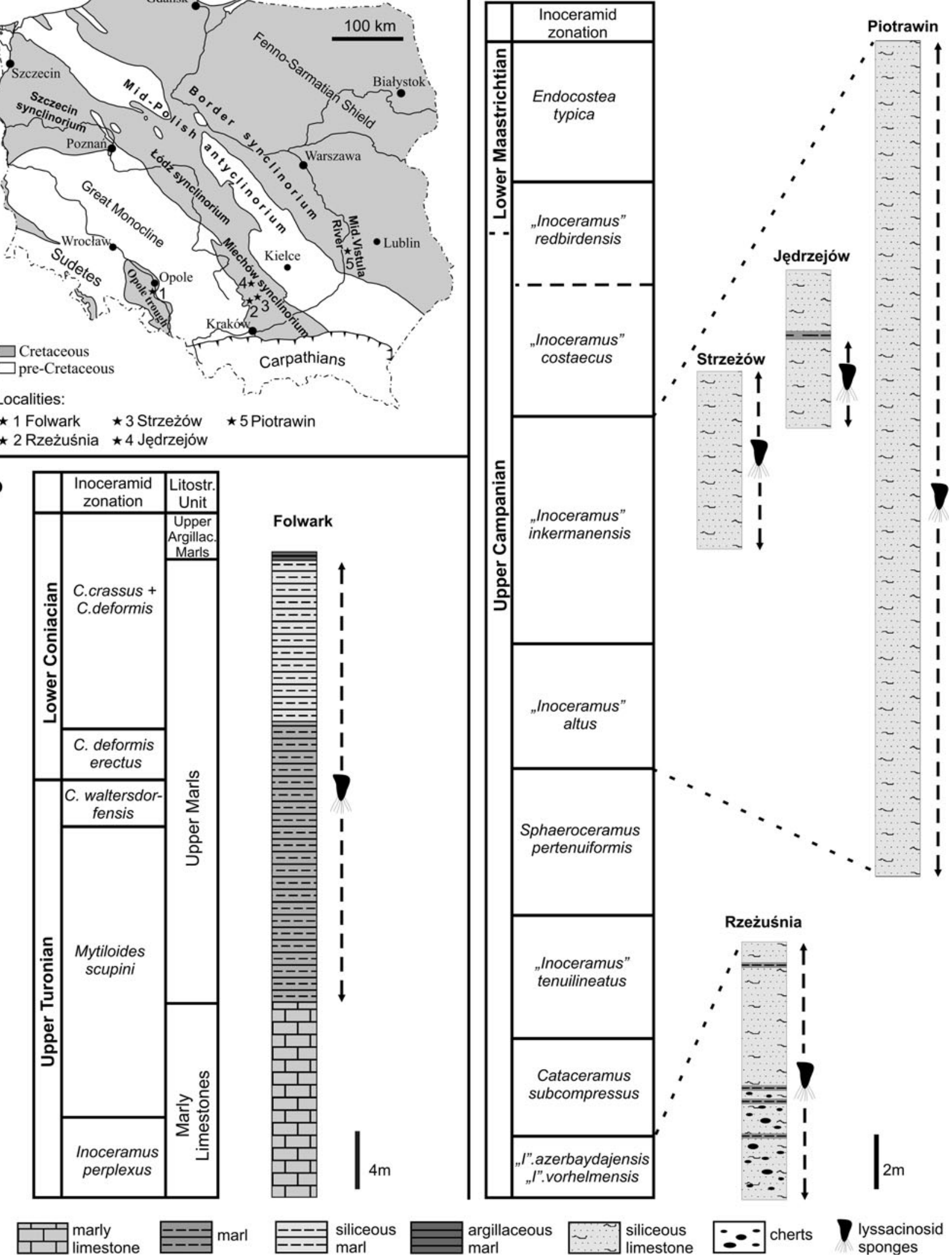

argillaceous marl
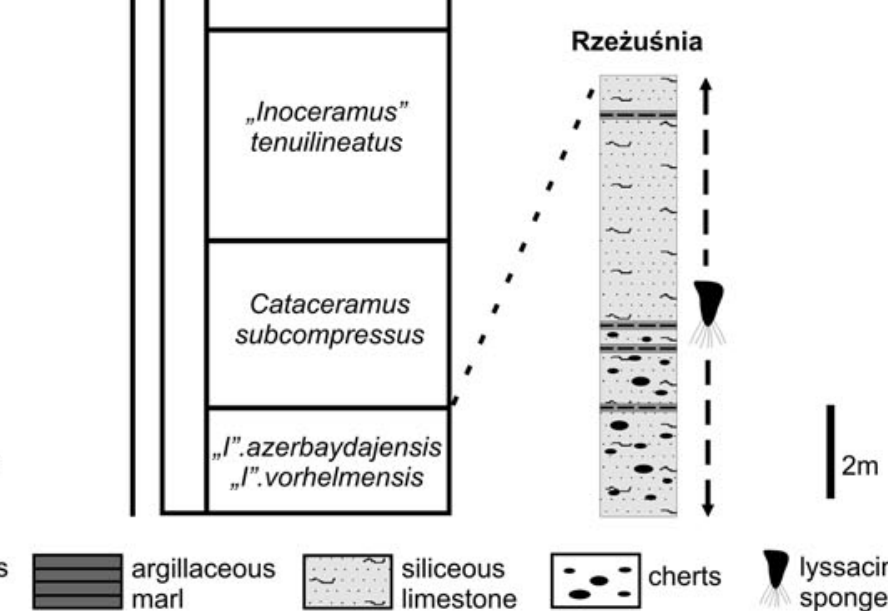

us $\quad \cdots \quad \begin{aligned} & \text { siliceous } \\ & \text { limestone }\end{aligned}$

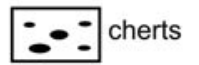

lyssacinosid sponges 

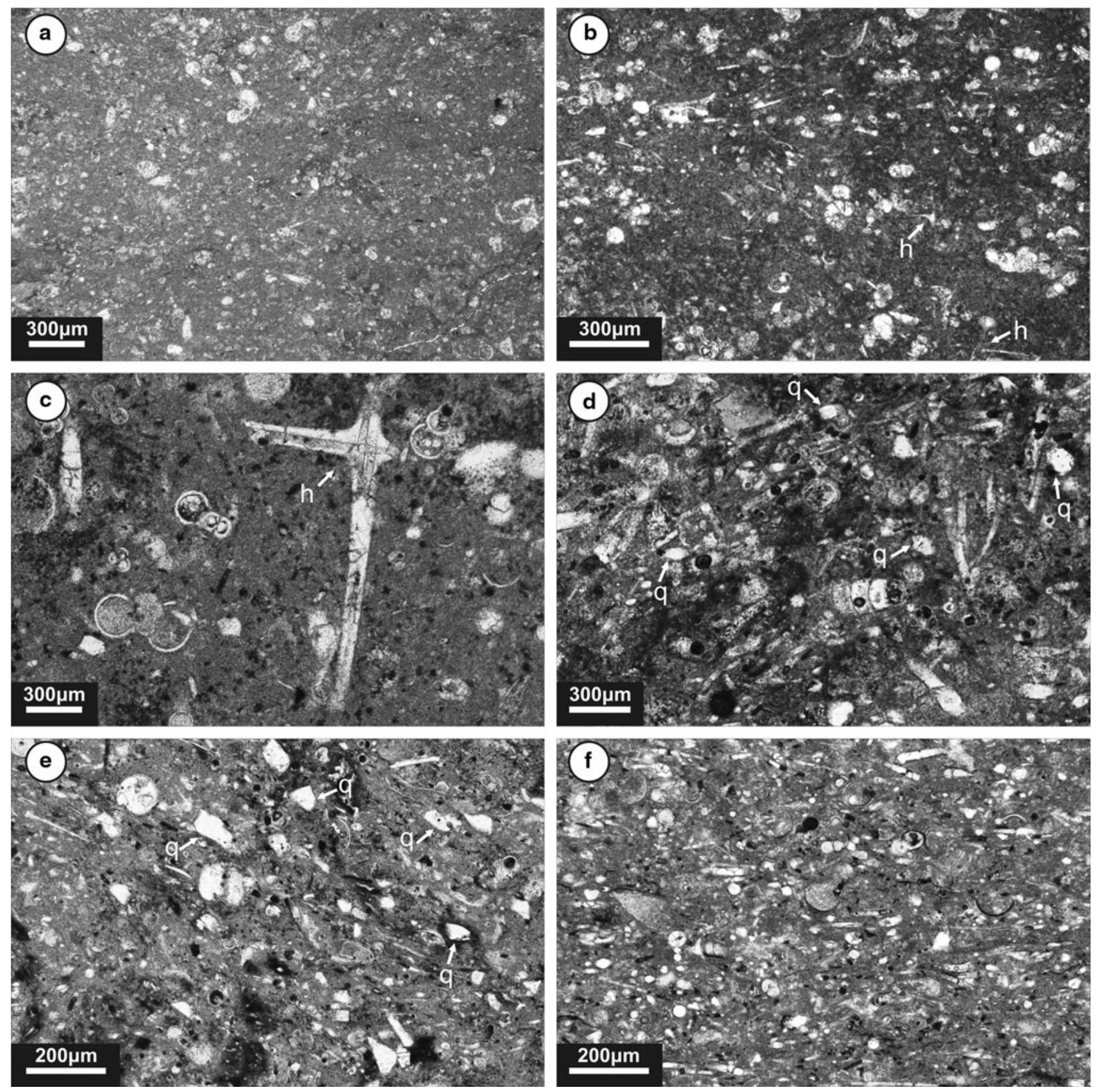

Fig. 2 Characteristic microfacies from the studied sections. a Foraminiferal wackestone from Folwark. b, c Packstone from Rzeżuśnia with foraminifers and sponge spicules, including loose hexactines (h). d, e Packstone with foraminifers and sponge spicules (mainly oxeas

Inoceramus vorhelmensis Interval Zone according to Jagt et al. (2004) and Walaszczyk et al. (2008)] opokas with cherts and marly intercalations. The relatively abundant fauna is dominated by inoceramids, gastropods, hexactinosid and lychniscosid sponges; less common are lithistid sponges and echinoids. Trace fossils are represented by Thalassinoides burrows. Lyssacinosids are very common, but only root tuft are preserved.

of soft demosponges); quartz grains (q) are significant. d Packstone from Strzeżów; e packstone from Jędrzejów. f Packstone with foraminifers and sponge spicules (mainly oxeas of soft demosponges) from Piotrawin

The Strzeżów section is an inactive quarry, with an Upper Campanian opoka succession, belonging to the "Inoceramus" inkermanensis and "Inoceramus" costaecus Zones (Jurkowska in prep.). The opokas are extremely fossiliferous, with abundant inoceramids, pectinids, gastropods, echinoids, and sponges (mainly hexactinosids and lychniscosids). Poorly preserved lyssacinosids appear throughout the succession. 
The Jędrzejów section was a temporary road cut in the northern part of the city of Jędrzejów. The succession is composed of opokas and marls of the "Inoceramus" inkermanensis Zone to "Inoceramus" costaecus_- Inoceramus" redbirdensis Zone (Jurkowska, in prep.). The "I". inkermanensis Zone is very fossiliferous, with abundant inoceramids, pectinids, belemnites, and echinoids. In the " $I$ ". costaecus and " $I$ ". redbirdensis Zones, echinoids and inoceramids become rare and big gastropods occur. Hexactinosid and lychniscosid sponges are numerous in the lower part of the succession but less common in the upper part where massive lithistids appear. Lyssacinosids are most numerous in the "I". inkermanensis Zone, while in the "I". redbirdensis Zone they are absent.

Microfacially, opokas from the studied sections represent packstone (Fig. 2b-e) with planktonic foraminifera and spicules of the siliceous sponges (mainly non-lithistid demosponges). In Rzeżuśnia, dispersed spicules of hexactinellid sponges also occur (Fig. 2c). In some thin-sections from Strzeżów, current alignment of spicules can be observed. Organic components also comprise fragments of bivalves and rare echinoids. An admixture of detritic material and glauconite was detected in Jędrzejów and Strzeżów; in Rzeżuśnia it is, however, insignificant.

All collected specimens of lyssacinosids are strongly limonitized. Rare, short fragments of siliceous or calcitized spicules have been found only in some specimens from Jędrzejów and Strzeżów. In all sections, root tufts type 1 are dominant. Large, fairly complete root tufts are preserved in life position while separated bundles of basal spicules lie horizontally.

\section{SE part of the border synclinorium}

In the SE part of the border synclinorium, the Upper Cretaceous succession is best exposed in the Middle Vistula River section (Pożaryski 1938; Marcinowski and Radwański 1983; Voigt et al. 2008) (Fig. 1a).

The Piotrawin section is an inactive quarry with a monotonous, poorly bedded succession of Upper Campanian opoka (Fig. 1c), which belongs to a local lithostratigraphic unit of Piotrawin Opoka (Walaszczyk 2004). Based on ammonites, Błaszkiewicz (1980) assigned the succession from this section to the Nostoceras pozaryskii Zone (=Nostoceras hyatti Zone according to Kennedy et al. 1992). Walaszczyk (2004) included its lower part into the "Inoceramus" altus Zone, whereas its middle and upper parts belong to the "Inoceramus" inkermanensis Zone.

The Piotrawin Opoka is extremely fossiliferous, with abundant siliceous sponges (Świerczewska-Gładysz 2006, 2012), ammonites (Błaszkiewicz 1980; Machalski 2012), belemnites (Kongiel 1962), inoceramids (Walaszczyk 2004) and non-ammonite molluscs (Abdel-Gawad 1986).
Microfacially, these opokas represent packstone (Fig. 2f) with foraminifera and spicules of siliceous sponges (mainly non-lithistid demosponges). Other bioclasts are fragments of bivalves, echinoderms, and rare bryozoans. Locally, in the upper part of the succession, current-aligned spicules are observed. Admixture of quartz and glauconitic grains is insignificant.

The lyssacinosid sponges are represented mainly by isolated root tufts. Bodily preserved sponges are much less numerous. Moreover, they are poorly preserved. All specimens are strongly limonitized and often only single spicules are visible. Fragments of siliceous spicules occur sporadically.

\section{Lyssacinosid sponges from the studied sections}

The studied material is dominated by isolated root tufts composed of basal spicules (spicules which protruded from the dermal surface and anchored sponges in the sediment).

Bodily preserved sponges are less numerous and, moreover, they are strongly deformed by compaction. They are usually incomplete, occasionally strongly fragmented with poorly visible single spicules. Better preserved specimens (described below) often possess only large spicules of the main (choanosomal) skeleton. Other taxonomically important spicules, such as autodermalia (megascleres supporting the dermal membrane directly), hypodermalia (megascleres lying under autodermalia), and supradermalia (megascleres protruding from the sponges surface), are rare. Microscleres, critical for the taxonomy of Recent taxa, have not been found. Due to their poor preservation, the taxonomic position of most of the sponges is uncertain.

Different types of spicules were recognized in studied specimens: monactines (one-rayed spicules), diactines (two-rayed spicules with rays aligned on the same axis), hexactines (spicules with six rays), and pentactines (hexactines with reduction of one ray) with four rays parallel to the body surface (tangential rays) intersecting at angles of $90^{\circ}$ (ortotropal pentactines) or intersecting at angles other than $90^{\circ}$ (paratropal pentactines).

Rossella rotunda Brückner, 2006

Figure $3 \mathrm{a}-\mathrm{c}$

Material

Three specimens from Folwark.

Description

The better preserved specimen is roundish, $35 \mathrm{~mm}$ in diameter (Fig. 3a). The round osculum on its top is $13 \mathrm{~mm}$ 

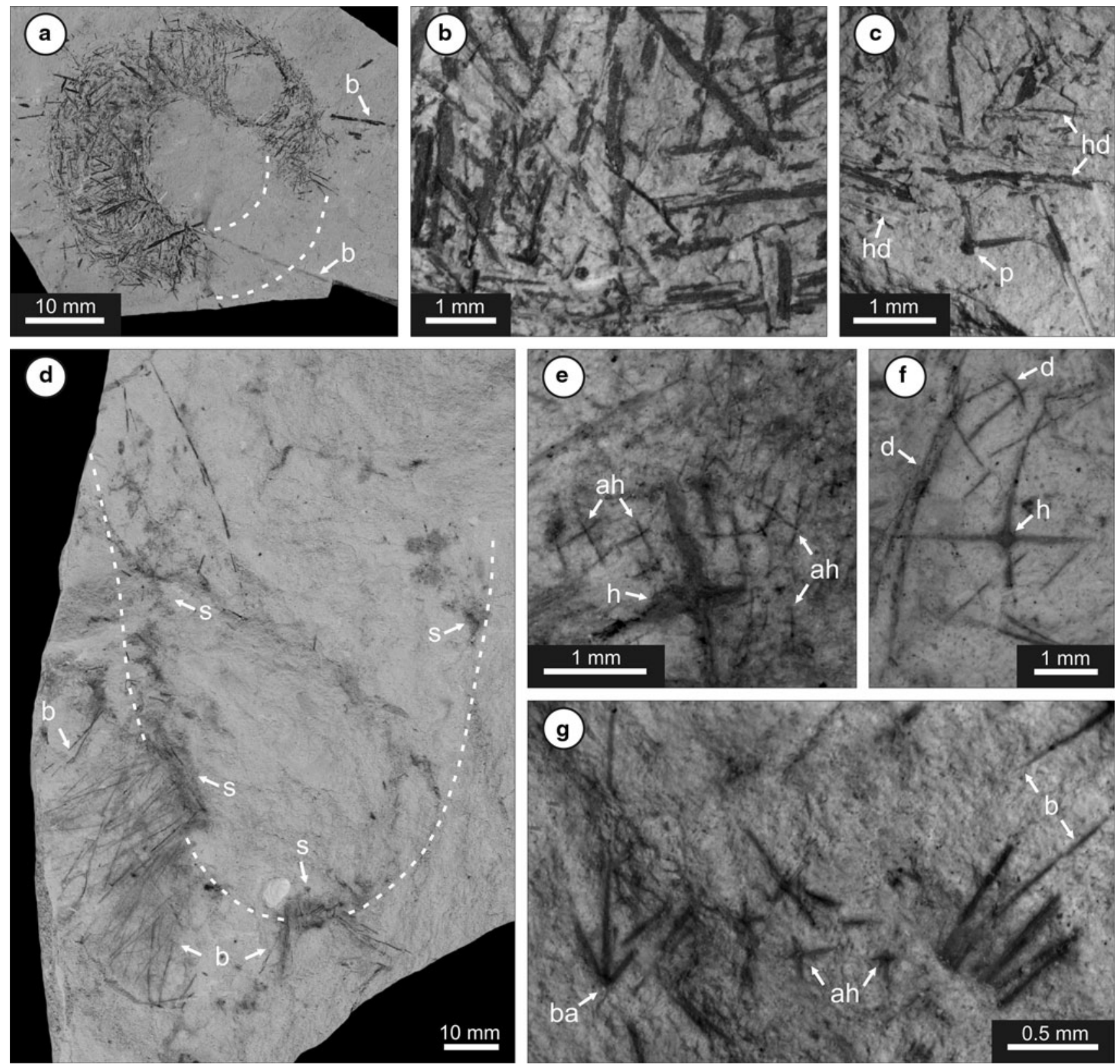

Fig. 3 a-c Rossella rotunda Brückner, 2006; Upper Turonian, Folwark, ULXXIII/F1. a Upper view of specimen; locally preserved are fragments of basal spicules (b). b Fragment of choanosomal skeleton with diactine bundles and isolated diactines. c Detail of skeleton with supradermal paratropal pentactine (p). d-g Rossella $\mathrm{cf}$. bromlei Brückner and Janussen, 2005. d Fragments of destructed sponge (s) and root tuft (b); Upper Campanian, Jędrzejów, ULXXIII/

in diameter. The height of the sponge is unknown, as the specimen was compressed almost parallel to its axis. The dense choanosomal skeleton is composed of variably oriented diactines and diactine bundles, up to 6-7 $\mathrm{mm}$ long (Fig. 3b). Small, 1-2-mm-long, hypodermal diactines are arranged parallel to the wall surface (Fig. 3c). Single autodermal hexactines, supradermal orthotropal pentactines,
J9. e Fragment of skeleton with autodermal hexactines (ah) and choanosomal hexactine (h); Upper Campanian, Jędrzejów, ULXXIII/ J9. f Detail of skeleton with choanosomal hexactine (h) and choanosomal diactines (d); Upper Campanian, Jędrzejów, ULXXIII/ J7. g Fragments of broken basal pentactines (b), basal pentactine with preserved anchor (ba) and dispersed autodermal hexactines (ah); Upper Campanian, Jędrzejów, ULXXIII/J7

paratropal pentactines (Fig. 3c), and fragments of few basal spicules occur (Fig. 3a).

\section{Remarks}

The basal spicules are fragmentary, and the anchors typical of the genus Rossella Carter, 1872 (see Tabachnick 2002c) 
are not preserved. The species has been so far reported from the Coniacian of Bornholm (Brückner 2006).

Rossella cf. bromlei Brückner and Janussen, 2005 Figure $3 \mathrm{~d}-\mathrm{g}$

\section{Material}

Four specimens from Jędrzejów and 1 specimen from Strzeżów.

\section{Description}

The sponges are probably cup-like (Fig. 3d) and more than $80 \mathrm{~mm}$ in height. All skeletons are strongly disintegrated. The spicules are scattered and their primary arrangement is occasionally unclear. The choanosomal skeleton is composed of isolated diactines (3-4 mm in length), diactine bundles (4-5 $\mathrm{mm}$ in length), and large hexactines (4-10 $\mathrm{mm}$ in size) (Fig. 3f). Supradermal pentacines are rare. Small autodermal hexactines $(0.5-0.9 \mathrm{~mm}$ in size), found in a well-preserved fragment, form a dense and quite regular lattice (Fig. 3e). Numerous autodermal hexactines and few choanosomal hexactines (probably derived from the lower part of the body) were also observed between basal spicules. Straight or wavy basal spicules are thin, with an average thickness of ca. $0.1 \mathrm{~mm}$. They comprise a dense, broad root tuft (Fig. 3d). Some of the basal pentactines are preserved with toothed anchors (Fig. 3g).

\section{Remarks}

All specimens are very poorly preserved with most of the spicules lost. Composition and size of the preserved spicules corresponds well to the diagnosis of $R$. bromlei from the Coniacian of Bornholm (compare Brückner and Janussen 2005; Brückner 2006).

\section{Chaunoplectella sp.}

Figure $4 \mathrm{a}, \mathrm{b}$

\section{Material}

Three specimens from Strzeżów and 2 specimens from Jędrzejów.

\section{Description}

The fragments are derived from thin-walled, probably cuplike sponges. The largest fragment, with a partly damaged wall, measures $160 \mathrm{~mm}$. These sponges are characterized by an irregular choanosomal skeleton (Fig. 4a, b) and are composed mainly of giant hexactines, with thick rays $(0.2-0.25 \mathrm{~mm})$, and up to $16 \mathrm{~mm}$ long. The rays of some hexactines are curved (Fig. 4a). Variably orientated diactines, $0.1 \mathrm{~mm}$ thick and $4-8 \mathrm{~mm}$ long, are less common (Fig. 4b). Locally small autodermal hexactines, with rays up to $1 \mathrm{~mm}$ in length, are preserved (Fig. 4b).

\section{Remarks}

In contrast to Recent thick-walled representatives of the genus Chaunoplectella Ijima, 1896 (Tabachnick 2002b), the specimens are characterized by a thin wall, similar to Chaunoplectella macrospiculata Brückner, 2006, from the Coniacian of Bornholm. The choanosomal hexactines of the specimens are distinctly larger than hexactines in Ch. macrospiculata where rays are up to $8 \mathrm{~mm}$ long (Brückner 2006). Recent representatives of Chaunoplectella are basiphytous with a short stalk. Bases in the studied specimens were not preserved.

Indeterminate genus and species $\mathrm{A}$

Figure $4 c, d$

\section{Material}

Five specimens from Jędrzejów and 1 specimen from Strzeżów.

\section{Description}

The fragments are derived from thin-walled (ca. $1 \mathrm{~mm}$ thick) tube- and cup-like sponges, up to $50-90 \mathrm{~mm}$ in diameter and over $150 \mathrm{~mm}$ in height. Occasionally they are preserved with broken single basal spicules or small fragments of dense root tuft. The characteristic feature of these sponges is their choanosomal skeleton, composed of diactine bundles and isolated diactines, which run parallel and diagonal in growth direction (Fig. 4c). The diactine bundles are large, $20-30 \mathrm{~mm}$ long. Isolated diactines are smaller, 10-15 $\mathrm{mm}$ long on average. The hexactines, also occurring in the choanosomal skeleton, are $2-8 \mathrm{~mm}$ in size (Fig. 4d). Dermal spicules are absent.

\section{Remarks}

A regular distribution of diactines and diactine bundles is known from the genus Regadrella Schmidt, 1880 from the Upper Cretaceous (Schrammen 1912; Brückner and Janussen 2005; Brückner 2006), as well as from several Recent genera of lyssacinosid sponges. Unfortunately, other features of the skeletons do not allow a precise taxonomic identification. 

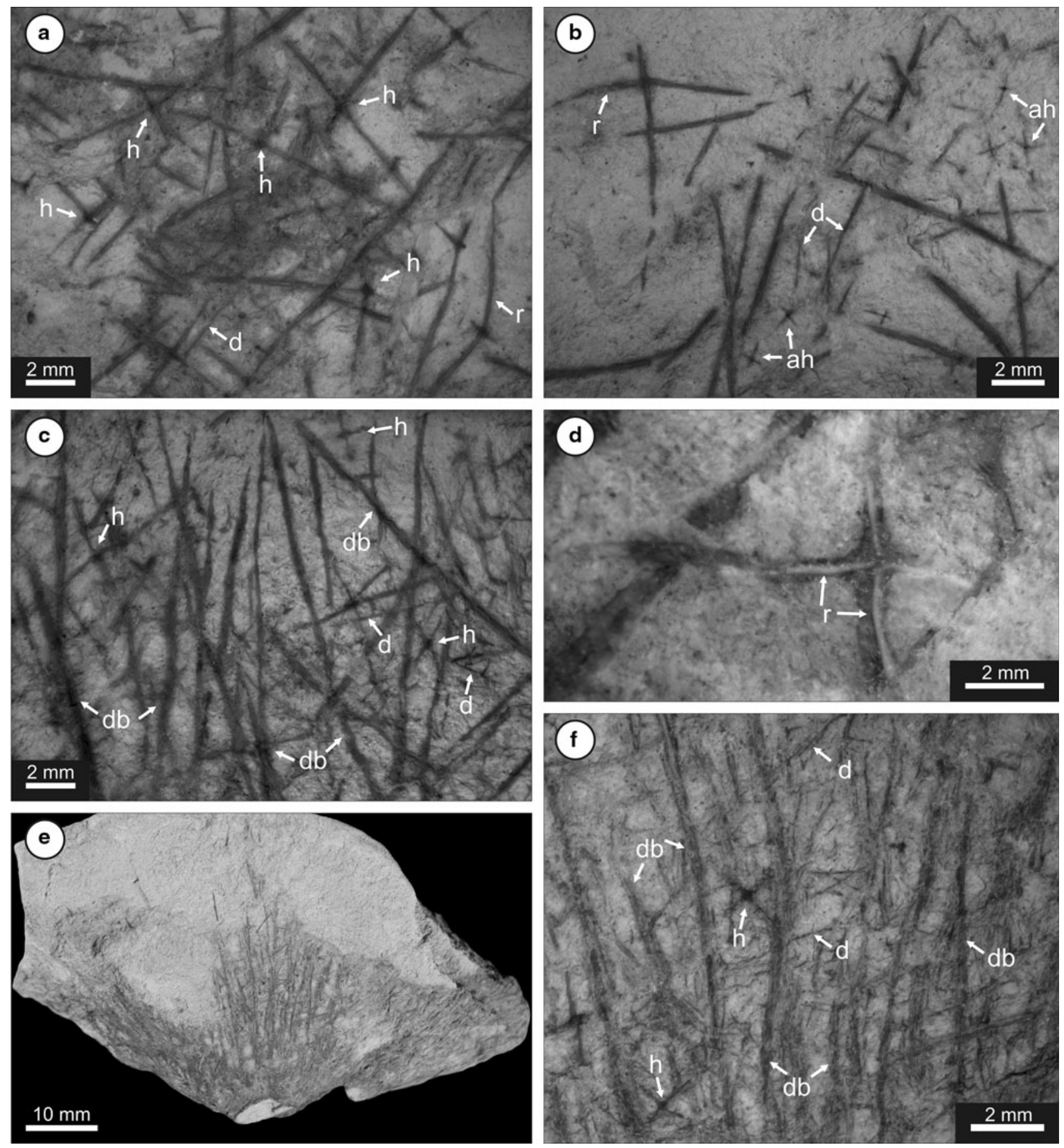

Fig. 4 a, b Chaunoplectella sp.; fragments of skeleton with large choanosomal hexactines (h), occasionally with curved rays (r), small choanosomal diactines (d), and autodermal hexactines (ah); Upper Campanian, Jędrzejów, UJ220P/38. c, d Indeterminate genus and species A; Upper Campanian, Jędrzejów, ULXXIII/J12. c Fragment of skeleton with oblique diactines bundles $(\mathrm{db})$, isolated diactines

(d) and choanosomal hexactines (h). d Choanosomal hexactine with preserved fragments of siliceous rays (r). e, f Indeterminate genus and species B; Upper Campanian, Piotrawin ULXXIII/P6. e Lateral view of specimen. f Fragment of skeleton with thick diactines bundles (db), isolated diactines (d), and choanosomal hexactines (h) 
Indeterminate genus and species $B$

Figure $4 \mathrm{e}, \mathrm{f}$

\section{Material}

One specimen from Piotrawin.

\section{Description}

This is a small, ca. 40-mm-high, thin-walled, cup-like sponge, with round to oval wall openings, 1-2 $\mathrm{mm}$ in diameter (Fig. 4e). The moderately dense skeletal lattice of this sponge is formed by long, thick $(0.5-0.8 \mathrm{~mm})$ diactine bundles, isolated diactines $(0.1 \mathrm{~mm}$ thick and up to $3 \mathrm{~mm}$ in long) and rare hexactines, up to $2 \mathrm{~mm}$ in size (Fig. 4f). The diactine bundles run mostly in growth direction. Other spicules are not visible.

Remarks

The lack of dermal spicules does not allow a precise taxonomic identification.

Indeterminate genus and species $\mathrm{C}$

\section{Material}

Three specimens from Folwark.

\section{Description}

These are wall fragments (up to $3 \mathrm{~cm}$ in size), derived from cup-like sponges. The wall is thin (up to $1 \mathrm{~mm}$ ) with irregularly distributed rounded or oval wall openings, $0.8-2 \mathrm{~mm}$ in diameter. The dense choanosomal skeleton consists of diactines, pointing in all directions, and of single hexactines. These spicules are poorly visible in a pyritized mass. The fragment of broad root tuft, preserved in the lower part of one of the specimen, is composed of thin (ca. $0.1 \mathrm{~mm}$ ), straight spicules with a broken terminal part. Others spicules were not observed.

\section{Remarks}

Because of their poor preservation, the specimens are left in open nomenclature.

Root tufts type 1

Figure 5a-d

\section{Material}

Nine specimens from Folwark, 35 from Rzeżuśnia, three from Strzeżów, five from Jędrzejów, and four from Piotrawin.
Description

The specimens are moderately dense, broad root tufts (Fig. 5a) composed of straight or slightly curved, thick $(0.2-0.3 \mathrm{~mm})$ spicules (Fig. $5 \mathrm{~d}$ ). The terminal parts of the spicules are not visible, but usually broken. The best-preserved specimens from Rzeżuśnia are very large, up to $250 \mathrm{~mm}$ long, and $160 \mathrm{~mm}$ wide (Fig. 5a). In the lower part of the root tufts, the spicules are loosely packed, the distance between them being up to 5-7 mm (Fig. 5b). A few specimens from Miechów synclinorium are represented by narrow (5-10 mm wide), separated bundles composed of few or several long spicules (Fig. 5c).

\section{Remarks}

Terminal parts of spicules forming these root tufts are not visible; thus a precise determination is impossible.

\section{Root tufts type 2}

Figure 5e, f

\section{Material}

One specimen from Piotrawin and 2 specimens from Rzeżuśnia.

\section{Description}

The specimens are composed of thin (0.05 mm thick), nonanchorate basal spicules which form narrow, separate, wavy tufts. The specimen from Piotrawin is composed of a fragment of the body and five separate tufts (up to $55 \mathrm{~mm}$ long and 2.5-3.5 mm wide) (Fig. 5f). The root tufts from Rzeżuśnia are broken and dispersed (Fig. 5e).

\section{Remarks}

The basalia gathered in several tufts are characteristic of some Recent genera of lyssacinosids of the family Euplectellidae Gray, 1867 (e.g., genus Chaunangium Schulze, 1904) and Rossellidae Schulze, 1885 (e.g., Lophocalyx Schulze, 1887) (Tabachnick 2002a, c). Numerous separate tufts are also typical of the genus Pheronema Leidy, 1868 (subclass Amphidiscophora Schulze, 1886), but basal spicules of the specimen do not have anchores typical of Pheronema (compare Tabachnick and Menshenina 2002b). Moreover, in the strongly damaged body fragment preserved with root tuft from Piotrawin, single diactines were recognized. These spicules are uncommon in Pheronema. 

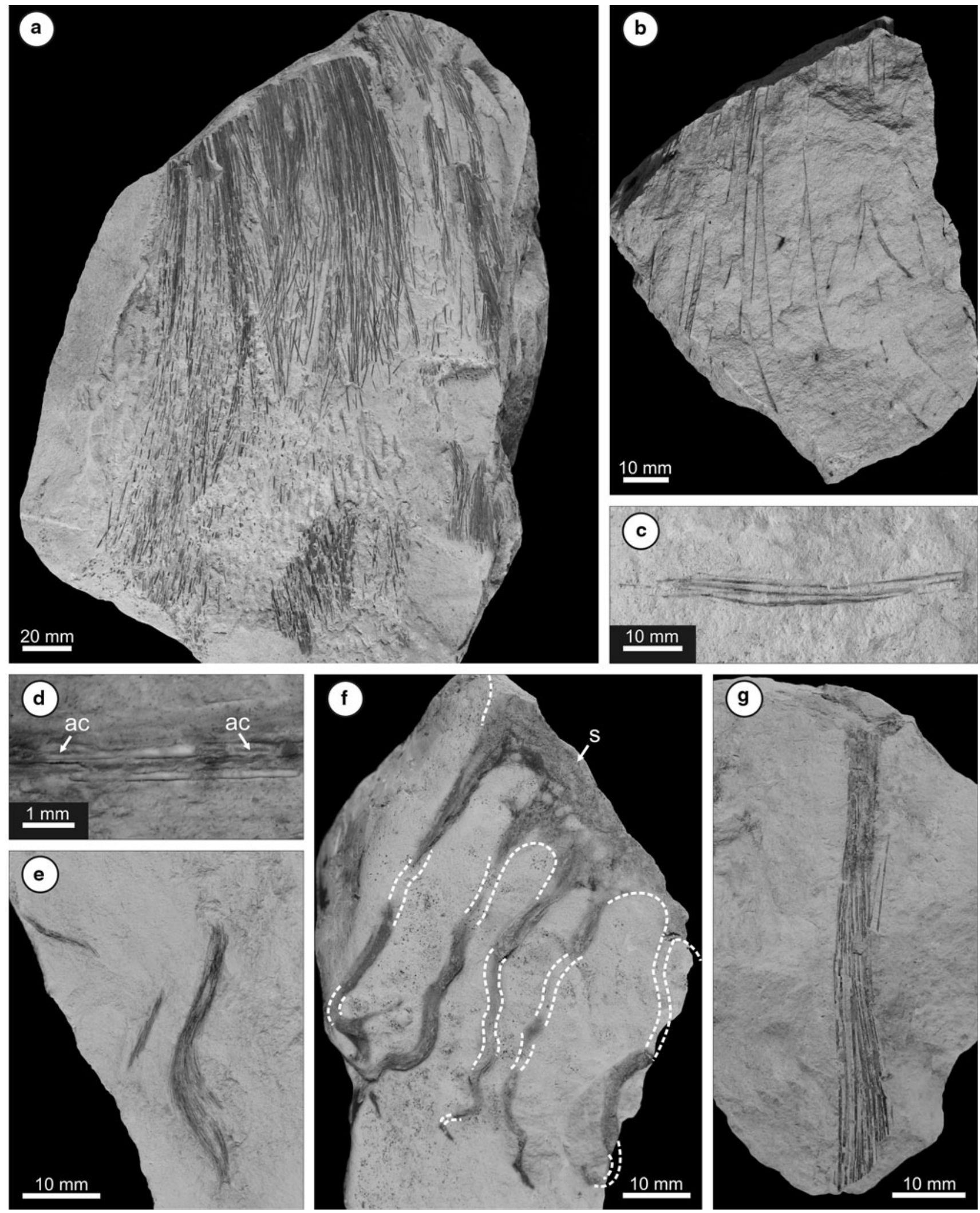
4 Fig. 5 a-d Root tufts type 1. a The largest specimen Upper Campanian, Rzeżuśnia, UJ220P/47/1. b Lower part of root tuft with loosely packed spicules; Upper Campanian, Strzeżów, UJ220P/34. c A few dispersed spicules, Upper Campanian, Rzeżuśnia, UJ 220P/ 26. d Preserved fragment of siliceous spicules with visible axial canal (ac); Upper Campanian, Piotrawin, ULXXIII/P10. e, f Root tufts type 2. e Three broken root tufts; Upper Campanian, Rzeżuśnia, UJ220P/ 12. f Specimen with five separated root tufts and body fragment (s); Upper Campanian, Piotrawin, ULXXIII/P11. g Root tuft type 3; Lower Coniacian, Folwark ULXXIII/F10

Root tufts type 3

Figure $5 \mathrm{~g}$

\section{Material}

One specimen from Folwark and two specimens from Piotrawin.

\section{Description}

Root tufts of type 3 are stalk-like with nearly parallel straight spicules (diactines?), 0.1-0.15 mm thick (Fig. 5g). In the lower part of root tufts, the spicules are slightly dispersed. The best-preserved root tuft from Folwark is over $65 \mathrm{~mm}$ long, $5 \mathrm{~mm}$ wide in the upper part, and ca. $8 \mathrm{~mm}$ wide in the lower part. Specimens from Piotrawin are large, over $90 \mathrm{~mm}$ in length and $15 \mathrm{~mm}$ wide. Terminal parts of all specimens are broken.

\section{Remarks}

Similar root tufts appear in several Recent lyssacinosids and in hyalonematid sponges (non-rigid hexactinellid sponges of the subclass Amphidiscophora Schulze, 1886). Sponges with stalk-like root tufts and some isolated stalklike root tufts from the Upper Cretaceous of Germany were described as the sole fossil representatives of the genus Hyalonema Gray, 1835 (Mehl and Hauschke 1995). Basal spicules of living hyalonematid sponges usually have 4-8 teeth (Tabachnick and Menshenina 2002a). Due to the lack of the characteristic toothed anchors of basal spicules, the attribution of the specimen to Hyalonema is uncertain.

\section{Paleoecological significance}

Most of the Recent Lyssacinosida live in the bathyal or even abyssal zone (e.g., Koltun 1967; Janussen et al. 2004; McClintock et al. 2005; Van Soest et al. 2007; Janussen and Reiswig 2009). Shallow-water (below $100 \mathrm{~m}$ ) lyssacinosids are known exclusively from circumpolar seas (e.g., Koltun 1970; McClintock et al. 2005), the fjords of British Columbia (e.g., Leys et al. 2004), submarine caves in the western Mediterranean (Boury-Esnault and Vacelet 1994) and southern New Zealand (Leys et al. 2004). The occurrence of hexactinellid sponges in these places is possible only under special conditions such as: low temperatures, quiet waters, and low light levels (Leys et al. 2004; Whitney et al. 2005).

The distribution of ancient hexactinellids shows that they were more common in the neritic zone than their Recent counterparts. Development of hexactinellid sponges in the Late Cretaceous was correlated with high sea levels (Pisera 1999). It is also likely that the occurrence of lyssacinosids and other hexactinellids in Cretaceous European epicontinental seas, was related to the upwelling zones of the Tethys Ocean (see e.g., Mehl and Niebuhr 1995). The studied sections are located clearly southward of the formerly reported occurrences of lyssacinosids; the Tethyan influence could have been significantly higher.

The morphology and life function of lyssacinosids suggest that they were adapted to a low sedimentation rate and low turbulence, therefore they are located almost invariably in deeper shelf areas (e.g., Wendt et al. 1989; Pisera and Busquets 2002; Beresi 2003). Only some thickwalled sponges from the Triassic might have lived below the fair-weather wave-base but above the storm wave-base (Pisera and Bodzioch 1991; Bodzioch 1994). In all of the studied sections, lyssacinosids are represented by thinwalled forms, similar to deep-water forms known from the Coniacian of Bornholm (Brückner 2006). Recent thinwalled $(<5 \mathrm{~mm})$ lyssacinosid sponges occur at depth of ca. $100 \mathrm{~m}$ or deeper (up to 7,000 m) (Tabachnick 2002a, c).

Some modern lyssacinosid sponges live on a hard substrate, attached by a basal plate. Although basal plates occur in some fossil species (Pisera and Bodzioch 1991; Bodzioch 1994), they were not found in the studied sponges, suggesting their adaptation to soft-bottom conditions. Such adaptation is also suggested by the occurrence of lophophytal sponges (with root tufts) and numerous isolated long root tufts in the material studied (compare Brückner et al. 2003; Brückner 2006). The presence of lophophytal lyssacinosid sponges was used as an indicator of soft bottom conditions by Reid (1962) for the English Chalk Rock. Soft-bottom conditions in the studied successions is also suggested by the presence of rhizoidal lychniscosid and hexactinosid sponges (see also Tarkowski 1991; Świerczewska-Gładysz 2006), infaunal echinoids (Mączyńska 1968; Olszewska-Nejbert 2007), and some bivalves (Abdel-Gawad 1986).

The inferred life conditions of the studied sponges are also supported by other paleontological and sedimentological data. Packstone with foraminifera and spicules suggest calm water condition with periodic activity of weak currents. Weak currents favor the development of Recent hexactinellids (Leys et al. 2004; Whitney et al. 
2005) and, consequently, are also inferred for the Cretaceous lyssacinosids.

Abundant lychniscosid and hexactinosid sponges, co-occurring with the studied lyssacinosids, indicate a deeper shelf environment (Świerczewska-Gładysz 2006). Moreover, some of these sponges [e.g., dish-shaped Ventriculites chonoides (Mantell, 1815) and Leiostracosia punctata (Schrammen, 1902)] indicate a very slow rate of sedimentation (Krautter 1997).

Thin-walled lyssacinosid sponges can only be preserved intact when quickly buried (Brückner et al. 2003; Brückner 2006). Most of the specimens studied herein have been partly destroyed due to a prolonged residence time on the sea floor, suggesting a slow rate of sedimentation in all of the successions. Quite often, only the root tufts that were buried in the sediment during the sponges' lifetime have been preserved (Leys et al. 2007). The isolated root tufts of lyssacinosids and other non-rigid hexactinellid sponges were often described from other assemblages of fossil sponges, e.g., from Eocene of Catalonia (Pisera and Busquets 2002) or Permian of Texas (Rigby et al. 2007). The lack of well-preserved specimens and occurrence of dispersed spicules in the Campanian deposits result most likely from a slow rate of sedimentation and periodic weak bottom currents, which prevented the accumulation of the sediment and favored destruction of skeletons of dead sponges. Small specimens are more complete and may have been buried relatively quickly.

The significance of Lyssacinosida for bathymetric interpretation is confirmed by their distribution in the Cretaceous of the Opole Trough. Their occurrence in the Upper Marl Unit and absence from the underlying Marly Limestone Unit suggest deepening of the Opole Basin during the latest Turonian and Early Coniacian. This agrees well with the current bathymetric interpretation of the succession based on ichnofabrics (Kędzierski and Uchman 2001) and analysis of shark assemblages (Niedźwiedzki and Kalina 2003).

During the Campanian, the present-day Middle Vistula Valley area and Miechów area were situated in the DanishPolish trough (Hakenberg and Świdrowska 1998). According to bathymetric interpretations based on noncephalopoda molluscs from the Middle Vistula River section, Upper Campanian Piotrawin opokas were deposited in a mid to outer shelf setting (Abdel-Gawad 1986).

In the uppermost Campanian ("I". costaecus-"I". redbirdensis zones) of the Jędrzejów section (Miechów area) Lyssacinosida are not observed, suggesting shallower water conditions. This is confirmed by the replacement of hexactinellid sponges by lithistids in these zones (e.g., Reid 1968; Ulbrich 1974). In the stratigraphically equivalent deposits of the Middle Vistula River section, where lychniscosid and hexactinosid sponges are less common,
Lyssacinosida have not been noted (ŚwierczewskaGładysz, 2012).

\section{Conclusions}

1. Although lyssacinosids have been rarely reported from benthic assemblages of European Late Cretaceous epicontinental seas, it seems that they were more abundant than suggested by previous studies. So far, Late Cretaceous lyssacinosids have been recorded from in England, France, Germany, and Denmark. Their presence in the Upper Cretaceous deposits of southern Poland indicates that during the Late Cretaceous they had a wide paleogeographic distribution in the North European province.

2. In the studied collection Rossella rotunda Brückner, 2006, Rossella cf. bromlei Brückner and Janussen, 2005, and Chaunoplectella sp were recognized. The taxonomic position of three other species is impossible to determine, because the specimens are poorly preserved without diagnostic spicules. Due to the lack of rigid skeletons, most of the specimens are strongly disintegrated, and occasionally only root tufts, composed of thick, long spicules, are preserved. In the studied section, three types of root tufts were recognized.

3. Cretaceous Lyssacinosids can be used as paleoenvironmental tools. The presence of thin-walled forms with root tufts indicates a soft bottom, slow rate of sedimentation, and calm and comparatively deep water conditions.

Acknowledgments We appreciate helpful comments by Dorte Janussen, Andrzej Pisera, and an anonymous reviewer. The authors are greatly indebted to Tadeusz Jurkowski, Jarosław Makieła, Krzysztof Paul, and Klaudiusz Salamon for help with the field work, to Beata Stożek for help with SEM photos, to Waldemar Obcowski and Grażyna Bartłomiejczyk for taking photographs of sponges, to Jarosław Szumny and Stanisław Olbrych for preparation of polished thin-sections, and to Aleksandra Wieczorek for linguistic corrections. The Institute of Geological Sciences Jagiellonian University Geology (grant No. PSP: K/DSC/000230) and Laboratory of Geology, University of Lodz (statutory fund, project 506/844) have supported this research.

Open Access This article is distributed under the terms of the Creative Commons Attribution License which permits any use, distribution, and reproduction in any medium, provided the original author(s) and the source are credited.

\section{References}

Abdel-Gawad GI (1986) Maastrichtian non-cephalopod molluscs (Scaphopoda, Gastropoda and Bivalvia) of the Middle Vistula Valley, Central Poland. Acta Geol Polon 31:69-224 
Alexandrowicz SW, Radwan D (1973) The Upper Cretaceous from the Opole Trough—stratigraphy and deposits. Prz Geol 4:183188 (in Polish)

Beresi MS (2003) Oxfordian sponge association from the Neuquén Basin, Mendoza, west central Argentina. J South Am Earth Sci 16:105-112

Błaszkiewicz A (1980) Campanian and Maastrichtian ammonites of the Middle Vistula River Valley, Poland; A stratigraphicpaleontological study. Pr Inst Geol 42:1-63

Bodzioch A (1993) Sponges from the epicontinental Triassic of Europe. In: Hagdorn H, Seilacher A (eds) Muschelkalk. Goldschneck, Stuttgart, pp 235-243

Bodzioch A (1994) Paleoecology of hexactinellid sponges from the epicontinental Triassic of Poland. In: Van Soest RWM, van Kempen TMG, Braekman JC (eds) Sponges in time and space. Balkema, Amsterdam, pp 35-44

Boury-Esnault N, Vacelet J (1994) Preliminary studies on the organization and development of a hexactinellid sponge from a Mediterranean cave, Oopsacas minuta. In: Van Soest RWM, van Kempen TMG, Braekman JC (eds) Sponges in time and space. Balkema, Rotterdam, pp 407-415

Bowerbank JS (1869) A monograph of the siliceo-fibrous sponges. Proc Zool Soc Lond 1869(66-100):323-351

Brückner A (2006) Taxonomy and paleoecology of lyssacinosan Hexactinellida from the Upper Cretaceous (Coniacian) of Bornholm, Denmark, in comparison with other Postpaleozoic representatives. Abh Senckenb Naturforsch Ges 564:1-103

Brückner A, Janussen D (2005) Rossella bromlei n. sp.: the first entirely preserved fossil sponge species of the genus Rossella (Hexactinellida) from the Upper Cretaceous of Bornholm, Denmark. J Paleont 79:21-28

Brückner A, Janussen D, Schneider S (2003) Eine neue PoriferenFauna aus dem Septarienton (Oligozän, Rupelium) von Bad Freienwalde (NE-Deutschland) und der erste fossil erhaltene Vertreter der nicht-rigiden Hexactinelliden-Gattung Asconema. Paläont Z 77:263-280

Carter HJ (1872) On two new sponges from the Antarctic Sea, and on a new species of Tethya from Shetland; together with observations on the reproduction of sponges commencing from zygosis of the sponge animal. Ann Mag Nat Hist 9(54):409-435

Delecat S, Reitner J (2005) Sponge communities from the Lower Liassic of Adnet (Northern Calcareous Alps, Austria). Facies 51: 385-404

Delecat S, Gernot A, Reitner J (2011) Aftermath of the TriassicJurassic Boundary Crisis: spiculite formation on drowned Triassic Steinplatte reef-slope by communities of hexactinellid sponges (Northern Calcareous Alps, Austria). Lect Notes Earth Sci 131(2011):355-390

Dresnay R, Termier G, Termier H (1978) Les hexactinellides (lyssakides et dictyonines) du Lias Marocain. Geobios 11:269295

Gehling JG, Rigby JK (1996) Long expected sponges from the Neoproterozoic Ediacara fauna of South Australia. J Paleont 70:185-195

Gray JE (1867) Notes on the arrangement of sponges, with the descriptions of some new genera. Proc Zool Soc 1867:492-558

Hakenberg M (1986) Albian and Cenomanian in the Miechów Basin (Central Poland). Studia Geol Polon 86:57-85

Hakenberg M, Świdrowska J (1998) Evolution of the Holy Cross segment of the Mid-Polish Trough during the Cretaceous. Geol Quart 42:239-262

Heller I, Moryc W (1984) Stratigraphy of the Upper Cretaceous deposits of the Carpathian Foreland. Biul Inst Geol 26:63-108 (in Polish)

Jagt JWM, Walaszczyk I, Yazykova EA, Zatoń M (2004) Linking southern Poland and northern Germany: Campanian cephalopods, inoceramids bivalves and echinoids. Acta Geol Polon 54:573-586

Janussen D, Reiswig HM (2009) Hexactinellida (Porifera) from the ANDEEP III Expedition to the Weddell Sea, Antarctica. Zootaxa 2136:1-20

Janussen D, Tabachnick KR, Tendal OS (2004) Deep-sea Hexactinellida (Porifera) of the Weddell Sea. Deep-Sea Res II 51:18571882

Kędzierski M (1995) Calcareous nannoplankton biostratigraphy of the Turonian and Coniacian of the Opole region, SW Poland. Prz Geol 43:406-408 (In Polish with English summary)

Kędzierski M (2008) Calcareous nannofossil and inoceramid biostratigraphies of a Middle Turonian to Middle Coniacian section from the Opole Trough of SW Poland. Cret Res 29:451-467

Kędzierski M, Uchman A (2001) Ichnofabrics of the Upper Cretaceous marlstones in the Opole region, southern Poland. Acta Geol Pol 51:81-91

Kennedy WJ, Cobban WA, Scott GR (1992) Ammonite correlation of the uppermost Campanian of Western Europe, the U.S. Gulf Coast, Atlantic Seaboard and Western Interior, and the numerical age of the base of the Maastrichtian. Geol Mag 129:497-500

Koltun VM (1967) Glass or hexactinellid sponges of the northern and far-eastern seas of the USSR (Class Hyalospongiae). Opred Faune SSSR, Izd Zool Akad Nauk 94:1-128 (in Russian)

Koltun VM (1970) Sponges of the Arctic and Antarctic; a faunistic review. Symp Zool Soc Lond 25:285-297

Kongiel R (1962) On belemnites from Maastrichtian, Campanian and Santonian sediments in the Middle Vistula Valley (Central Poland). Pr Muz Ziemi 5:1-198

Krautter M (1997) Aspekte zur Paläökologie postpaläozoischer Kieselschwämme. Profil 11:199-324

Krautter M (2002) Fossil Hexactinellida: an overview. In: Hooper JNA, van Soest RWM (eds) Systema Porifera: a guide to the classification of sponges. Kluwer Academic, New York, pp 1211-1223

Leonhard R (1897) Die Fauna der Kreideformation in Oberschlesien. Palaeontographica 44:11-70

Leys SP, Wilson K, Holeton C, Reiswig HM, Austin WC, Tunniclif V (2004) Patterns of glass sponge (Porifera, Hexactinellida) distribution in coastal waters of British Columbia, Canada. Mar Ecol Progr Ser 283:133-149

Leys SP, Mackie GO, Reiswig H (2007) The biology of glass sponges. Adv Mari Biol 52:1-145

Machalski M (2012) Stratigraphically important ammonites from the Campanian-Maastrichtian boundary interval of the Middle Vistula River section, Central Poland. Acta Geol Polon 62:91-116

Mączyńska SS (1968) Echinoids of the genus Micraster L. Agassiz from the Upper Cretaceous of the Cracow-Miechow area. Pr Muz Ziemi 12:87-164

Mantell G (1815) Description of a fossil Alcyonium from the Chalk Strata of Lewes. Trans Linn Soc Lond 22:401-407

Marcinowski R (1970) The Cretaceous transgressive deposits east of Częstochowa (Polish Jura Chain). Acta Geol Polon 20:412-449

Marcinowski R (1974) The transgressive Cretaceous (Upper Albian trough Turonian) deposits of the Polish Jura Chain. Acta Geol Polon 24:117-217

Marcinowski R, Radwański A (1983) The Mid-Cretaceous transgression onto the Central Polish Uplands (marginal part of the Central European Basin). Zitteliana 10:65-95

Marcinowski R, Radwański A (1989) A biostratigraphic approach to the mid-Cretaceous transgressive sequence of the Central Polish Uplands. Cret Res 10:153-172

McClintock JB, Amsler CD, Baker BJ, van Soest RWM (2005) Ecology of Antarctic marine sponges: an overview. Integr Comp Biol 45:359-368 
Mehl D (1992) Die Entwicklung der Hexactinellida seit dem Mesozoikum, Paläobiologie, Phylogenie und Evolutionsökologie. Berl Geowiss Abh E2:1-164

Mehl D, Hauschke N (1995) Hyalonema cretacea $\mathrm{n}$. sp., first bodily preserved Amphidiscophora (Porifera, Hexactinellida) from the Mesozoic. Geol Paläont Westf 38:89-97

Mehl D, Niebuhr B (1995) Diversität und Wachstumsformen bei Coeloptychium (Hexactinellida, Lychniskosa) der Meiner Mulde (Untercampan, N-Deutschland) und die Palökologie der Coeloptychidae. Berl Geowiss Abh E16:91-107

Moret L (1926) Contribution à l'étude des spongiaires siliceux du Crétacé supérieur français. Mém Soc Géol France N Ser 5:1-267

Mostler H (1989) Mikroskleren hexactinellider Schwämme aus dem Lias der Nördlichen Kalkalpen. Jb Geol B Wien 132:687-700

Niedźwiedzki R, Kalina M (2003) Late Cretaceous sharks in the Opole Silesia region (SW Poland). Geol Sudet 35:13-24

Olszewska-Nejbert D (2007) Late Cretaceous (Turonian-Coniacian) irregular echinoids of western Kazakhstan (Mangyshlak) and Poland (Opole). Acta Geol Polon 57:1-87

Pisera A (1999) Postpaleozoic history of the siliceous sponges with rigid skeleton. Mem Queensl Mus 44:463-472

Pisera A, Bodzioch A (1991) Middle Triassic lyssacinosan sponges from the Upper Silesia (southern Poland) and the history of hexactinosan and lychniscosan sponges. Acta Geol Polon 41:193-207

Pisera A, Busquets P (2002) Eocene siliceous sponges from the Ebro Basin (Catalonia, Spain). Geobios 35:321-346

Pożaryski W (1938) Senonstratigraphie im Durchbruch der Weichsel zwischen Rachów und Puławy in Mittelpolen. Biul Inst Geol 6:194 (in Polish with German summary)

Pożaryski W (1960) An outline of stratigraphy and palaeogeography of the Cretaceous in the Polish Lowland. Pr Inst Geol 30:377-418 (in Polish with English summary)

Reid REH (1962) Relationships of fauna and substratum in the paleoecology of the Chalk and Chalk Rock. Nature 194:276-277

Reid REH (1968) Hexactinellid faunas in the Chalk of England and Ireland. Geol Mag 105:15-22

Rigby JK, Gosney TC (1983) First reported Triassic lyssakid sponges from North America. J Paleont 57:787-796

Rigby JK, Bell GL Jr, Thompson K (2007) Hexactinellid and associated sponges from the upper Reef Trail Member of the Bell Canyon Formation, southern Guadalupe Mountains National Park, Texas. J Paleont 81:1241-1256

Roemer F (1870) Geologie von Oberschlesien. L. Köhler, Breslau 587 p

Rutkowski J (1965) Senonian of the Miechów area, southern Poland. Rocz Pol Tow Geol 31:1-47 (in Polish)

Salomon D (1990) Ein neuer lyssakiner Kieselschwamm, Regadrella leptotoichica (Hexasterophora, Hexactinellida) aus dem Untercenoman von Baddeckenstedt (Nordwestdeutschland). N Jb Geol Paläont Mh 1990:342-352

Schmidt O (1870) Grundzüge einer Spongien-Fauna des atlantischen Gebietes. Wilhelm Engelmann, Leipzig, iii-iv, p 88

Schrammen A (1902) Neue Hexactinelliden aus der oberen Kreide. Mitt Roemer-Mus 15:1-26

Schrammen A (1912) Die Kieselspongien der oberen Kreide von Nordwestdeutschland. II. Triaxonia (Hexactinellida). Palaeontographica Suppl 5:177-385

Schrammen A (1937) Die Kieselspongien des oberen Jura von Süddeutschland. B. Besonderer Teil. Palaeontographica 85:1114

Schulze FE (1887) Report on the Hexactinellida collected by H.M.S. 'Challenger' during the years 1873-1876. Rep Scient Res Challenger Zool 21:1-514

Schulze FE (1904) Hexactinellida. Wissenschaftliche Ergebnisse der Deutschen Tiefsee-Expedition auf der Dampfer 'Valdivia' 1898-1899 4:1-266
Świdrowska J, Hakenberg M (1999) Subsidence and the problem of incipient inversion in the Mid-Polish Trough based on thickness maps and Cretaceous lithofacies analysis. Prz Geol 47:61-68 (in Polish with English summary)

Świerczewska-Gładysz E (2006) Late Cretaceous siliceous sponges from the Middle Vistula River Valley (Central Poland) and their palaeoecological significance. Ann Soc Geol Polon 76:227-296

Świerczewska-Gładysz (2012) Changes in hexactinellid sponge assemblages across the Campanian-Maastrichtian boundary of the Middle Vistula river section (central Poland). Acta Geol Polon (in press)

Tabachnick K (2002a) Family Euplectellidae Gray, 1867. In: Hooper JNA, van Soest RWM (eds) Systema Porifera: a guide to the classification of sponges. Kluwer Academic, New York, pp 1388-1434

Tabachnick K (2002b) Family Leucopsacidae Ijima, 1903. In: Hooper JNA, van Soest RWM (eds) Systema Porifera: a guide to the classification of sponges. Kluwer, New York, pp 1435-1440

Tabachnick K (2002c) Family Rossellidae Schulze, 1885. In: Hooper JNA, van Soest RWM (eds) Systema Porifera: a guide to the classification of sponges. Kluwer, New York, pp 1441-1505

Tabachnick K, Menshenina LL (2002a) Family Hyalonematidae Gray, 1857. In: Hooper JNA, van Soest RWM (eds) Systema Porifera: a guide to the classification of sponges. Kluwer Academic, New York, pp 1232-1263

Tabachnick K, Menshenina LL (2002b) Family Pheronematidae Gray, 1870. In: Hooper JNA, van Soest RWM (eds) Systema Porifera: a guide to the classification of sponges. Kluwer, New York, pp 1267-1280

Tarkowski R (1991) Stratigraphy, macrofossils and palaeogeography of the Upper Cretaceous from the Opole Trough. Zesz Nauk AGH 51:3-156 (in Polish with English summary)

Ulbrich H (1974) Die Spongien der Ilsenburg-Entwicklung (Oberes Unter-Campan) der Subherzynen Kreidemulde. Freiberger Forschh C 291:1-121

Van Soest RWM, van Duyl FC, Maier C, Lavaleye MSS, Beglinger E, Tabachnick KR (2007) Mass occurrence of the hexactinellid Rossella nodastrella Topsent in bathyal coral reefs of Rockall Bank, W of Ireland (Lyssacinosida, Hexactinellida). In: Custódio MR, Lôbo-Hajdu G, Hajdu E, Muricy G (eds) Trends in Porifera research-biodiversity, innovation, sustainability. Proc 7th Int Sponge Conf, Buzios May 2006, Universidade de Sao Paulo, pp 6-13

Voigt S, Wagreich M, Surlyk F, Walaszczyk I, Ulicny D, Cech S, Voigt T, Wiese F, Wilmsen M, Niebuhr B, Reich M, Funk H, Michalik J, Jagt JWM, Felder PJ, Schulz AS (2008) Cretaceous. In: McCann T (ed) Geology of Central Europe, vol 2., Mesozoic and Cenozoic. The Geological Society of London, London, pp 923-997

Walaszczyk I (1988) Inoceramid stratigraphy of the Turonian and Coniacian striata in the environs of Opole (southern Poland). Acta Geol Pol 38:51-61

Walaszczyk I (1992) Turonian trough Santonian deposits of the Central Polish Uplands; their facies development, inoceramid paleontology and stratigraphy. Acta Geol Polon 42:1-122

Walaszczyk I (2004) Inoceramids and inoceramie biostratigraphy of the Upper Campanian to basal Maastrichtian of the Middle Vistula River section, central Poland. Acta Geol Polon 54:95-168

Walaszczyk I, Cobban WA (2000) Inoceramid faunas and biostratigraphy of the Upper Turonian-Lower Coniacian of the United States Western Interior. Palaeontol Spec Pap 64:1-117

Walaszczyk I, Wood CJ (1998) Inoceramid biostratigraphy at the Turonian/Coniacian boundary; based on the Salzgitter-Salder Quarry, Lower Saxony, Germany, and the Słupia Nadbrzeżna section, Central Poland. Acta Geol Polon 48:395-434 
Walaszczyk I, Cobban WA, Wood ChJ, Kin A (2008) The "Inoceramus" azerbaydajensis fauna (Bivalvia) and its value from chronostratigraphic calibration of the European Campanian (Upper Cretaceous). Bull Inst R Sci Nat Belg 78:229-238

Wendt J, Wu X, Reinhardt JW (1989) Deep-water hexactinellid sponge mounds from the upper Triassic of northern Sichuan (China). Palaeogeogr Palaeoclimatol Palaeoecol 76:17-29

Whitney F, Conway KW, Thomson RE, Barrie JV, Krautter M, Mungov G (2005) Oceanographic habitat of sponge reefs on the
Western Canadian Continental Shelf. Contin Shelf Res 25:211-226

Wu X (1989) Carnian (Upper Triassic) sponge mounds of the northwestern Sichuan Basin, China: stratigraphy, facies and paleoecology. Facies 21:171-188

Zittel KA (1877) Studien über fossile Spongien. I: Hexactinellidae. Abh Math-Phys Cl Kgl Bayer Akad Wiss 13:1-63 